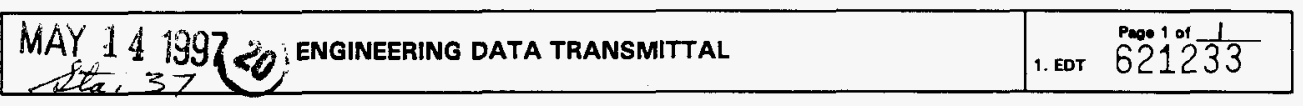

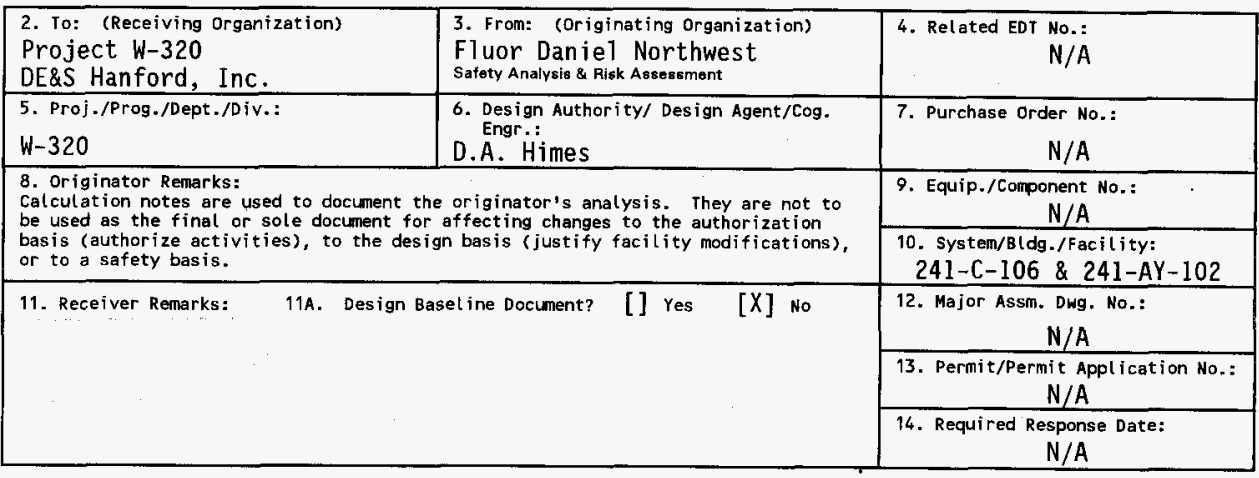

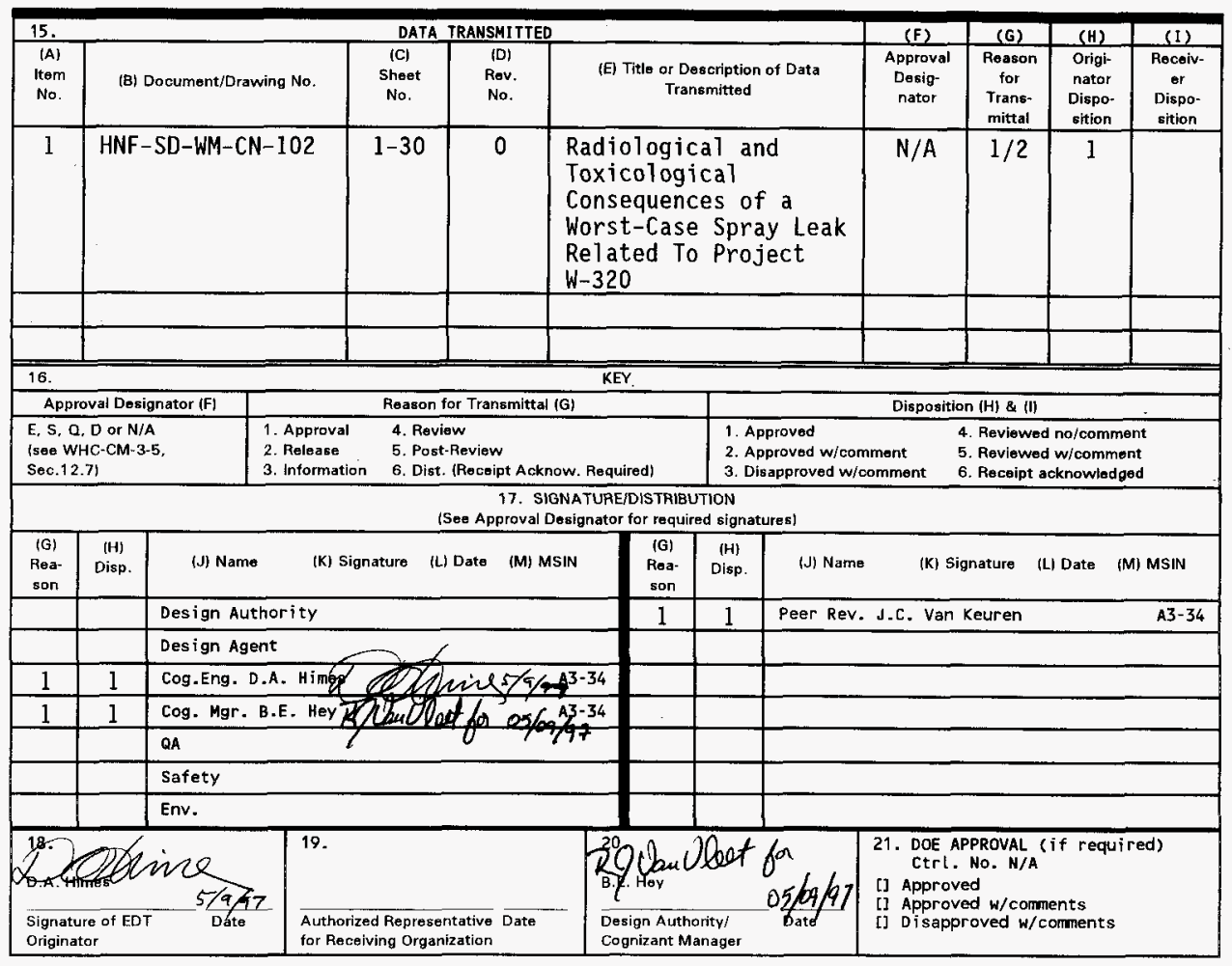

BD-7400-172-2 (05/96) GEF097 


\title{
Radiological and Toxicological Consequences of a Worst-Case Spray Leak Related To Project W-320
}

\author{
D.A. Himes
}

Fluor Daniel Northwest Inc., Richland, WA 99352

U.S. Department of Energy Contract DE-AC06-96RL13200

\author{
EDT/ECN: 621233 UC: 510 \\ Org Code: 403 Charge Code: E09120/P3EU00 \\ B\&R Code: EW3130010 Total Pages: 30
}

Key Words: Spray Leak, W-320

Abstract: An analysis was performed of radiological and toxicological consequences of a worst-case leak from a 2-inch diameter flush connection in a pit over tank AY-102. The unmitigated (without controls) flush line spray leak assumes that the blank connector and the removable plug in the pit cover block have been removed so that the maximum system flow is directed out of the open 2-inch 1ine vertically into the air above the pit. The mitigated (with controls) spray scenario assumes the removable plug is in place and the flow is directed against the underside of the pit cover block. The unmitigated scenario exceeded both onsite and offsite risk guidelines for an anticipated accident. For the mitigated case all consequences are well within guidelines and so no additional controls are needed beyond the existing control of having all pit covers and removable plugs in place during any waste transfer.

TRADEMARK DISCLAIMER. Reference herein to any specific commercial product, process, or service by trade name, trademark, manufacturer, or otherwise, does not necessarily constitute or imply its endorsement, recommendation, or favoring by the United States Government or any agency thereof or its contractors or subcontractors.

Printed in the United States of America. To obtain copies of this document, contact: Document Control Services, P.O. Box 950, Mailstop H6-68, Richland WA 99352, Phone (509) 372-2420; Fax (509) 376-4989.
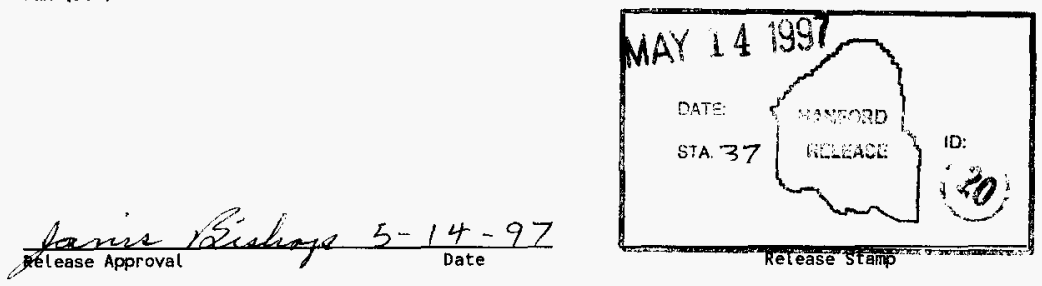

Approved for Public Release 


\title{
HNF-SD-WM-CN-102 Rev 0 \\ RADIOLOGICAL AND TOXICOLOGICAL CONSEQUENCES OF A WORST-CASE SPRAY LEAK RELATED TO PROJECT W-320
}

\author{
D.A. Himes \\ $3 / 31 / 97$
}

During sluicing operations in Tank 241-C-106, supernate liquid from Tank 241AY-102 and slurry of varying composition from C-106 will be pumped under pressure between the two tanks. During the operation, should containment barriers breach somewhere along the transfer route, a pressurized spray release to the environment could occur. Pressurized spray releases are of safety concern because they can be relatively efficient generators of respirable sized aerosols. Spray releases can result from small holes or cracks in transfer piping, improperly installed transfer jumpers, or defective or degraded seals or gaskets on pumps and valves. Mechanisms such as aging, corrosion, erosion, water hammer, overpressure, freezing, mechanical fatigue, thermal stresses, construction flaws, and human error can lead to these failures. Spray leaks can also occur due to misroutes through compromised piping or jumpers. Spray leaks such as these are bounded by those already analyzed in the existing TWRS safety documentation. Radiological and toxicological consequences of spray leak accidents in Hanford liquid waste tank farm pits were previously estimated and reported in WHC-SD-WM-CN-048 Rev 1, Calculation Notes in Support of TWRS FSAR Spray Leak Accident Analysis (Hall 1996) in support of the Tank Waste Remediation System (TWRS) Final Safety Analysis Report (FSAR), and further analyzed in HNF-SD-WM-CN-096 Rev 0, Refined Radiological and Toxicological Consequences of Bounding Spray Leak Accidents in Tank Farm Waste Transfer Pits (Himes 1997).

The only such accident related to Project $W-320$ which has not been previously considered is associated with the sluice line and slurry line flush connections located in pits over tank AY-102 (the highest elevation in the system). These connections are 2-inch (nominal) diameter pipes directed vertically upward under removable plugs in the pit cover blocks. The flush connections are normally closed by blanked jumper-type connectors. The unmitigated (without controls) flush line spray leak assumes that the blank connector and the removable plug in the pit cover block have been removed so that the maximum system flow is directed out of the open 2-inch line vertically into the air above the pit. The mitigated (with controls) spray scenario assumes the removable plug is in place and the flow is directed against the underside of the pit cover block. Previous analysis (attachment 1) has shown that maximum flow from the connection is not sufficient to lift the $3501 \mathrm{~b}$ removable plug. These scenarios were analyzed for both the sluice line (high flow rate, low solids content) and the slurry return line (lower flow, high solids content) to determine worst-case radiological and toxicological consequences. 


\section{HNF-SD-WM-CN-102 Rev 0}

\section{Spray Leak Scenarios:}

Two bounding accident scenarios have been chosen to represent the range of flush connector spray leaks which could occur in the sluice and pump pits over Tank 241-AY-102.

$\Rightarrow \quad$ An unmitigated release of waste issuing from a flush connection over AY102. The pit cover plug over the flush connection was assumed to be removed and the stream to be directed vertically upward. Both a slurry line release from the 241-AY-02A pump pit and a sluice 1 ine release from the 241-AY-02E sluice pit were evaluated to determine the worst case. Both flush connections are nominal 2 inch schedule 40 pipe with an inside diameter of 2.067 inches. In the case of the sluice line, the pump is very close to the open flush connection and will run at maximum speed $(3,056 \mathrm{rpm})$ assuming no discharge head. The maximum flow rate under these conditions is $650 \mathrm{gpm}(41.0 \mathrm{~L} / \mathrm{s})$ with a discharge velocity at the $\mathrm{flush}$ connection of $65.3 \mathrm{ft} / \mathrm{s}(19.9 \mathrm{~m} / \mathrm{s}$ ) (see attachment 2).

In the case of the slurry line returning from $\mathrm{C}-106$, the flush connection is at an elevation $35 \mathrm{ft}$ higher than the slurry pump and the material must traverse about $2000 \mathrm{ft}$ of pipe run. The flush connection is, in fact, very close to, but at a higher elevation, than the slurry distribution nozzles in $A Y-102$. The flow from the flush connection would therefore be expected to be about the same as the normal $350 \mathrm{gpm}$ flow rate for the slurry line. For this analysis, however, the flow was conservatively assumed to be $450 \mathrm{gpm}(28.4 \mathrm{~L} / \mathrm{s})$, or about $100 \mathrm{gpm}$ above the expected flow rate. The corresponding flow velocity from the flush connection was estimated to be $45.2 \mathrm{ft} / \mathrm{s}(13.8 \mathrm{~m} / \mathrm{s})$. Consistent with previous spray release analyses in the TWRS safety documentation, the flush connection release was assumed to continue unabated for 24 hours.

$\Rightarrow \quad$ A mitigated release of waste issuing from a flush connection over AY102. The conditions are the same as assumed above except the removable plug in the pit cover block over the flush connection was assumed to be in place. As before, both a slurry line release within the 241-AY-02A pump pit and a sluice 7 ine release within the 241-AY-02E sluice pit were evaluated to determine the worst case. The impact of the stream on the underside of the pit cover was assumed to saturate the air within the pit to the maximum sustainable air loading of $100 \mathrm{mg} / \mathrm{m}^{3}$ (ANSI $\mathrm{N} 46.1$ 1980). The direct aerosol release is then carried with the air displaced from the pit while it fills with slurry. Note that the total amount of air displaced from the pit is $35 \%$ more than the volume of the pit due to an initial expansion of the air due to an assumed increase in air temperature and relative humidity from $30^{\circ} \mathrm{F}$ at $15 \% \mathrm{R} . \mathrm{H}$. to $120^{\circ} \mathrm{F}$ at $100 \%$ R.H. (Hall 1996). After the pit fills the spray release would end and the slurry would spread over the ground above the pit as a pool. The analysis of pool releases is the subject of another document and is outside the scope of this analysis. 


\section{HNF-SD-WM-CN-102 Rev 0}

Both the AY-02A and AY-02E pits are equipped with 6-inch high capacity drains emptying directly into tank AY-102 (see Attachment 2). These drains are designed to handle the maximum flow from an open transfer line. In addition, both pits are equipped with leak detectors which would alarm before the liquid reached the levels of the high capacity drains. For purposes of this bounding analysis, the high capacity drains were assumed to be blocked and no credit was taken for the leak detectors. Since a negative pressure is maintained in the pits via the drains to $A Y-102$, the consequences with the drains working would be far less severe.

\section{Atmospheric Transport:}

Receptor locations and atmospheric dispersion factors $\left(X / Q^{\prime}\right)$ were developed and are reported in WHC-SD-WM-SARR-016, Tank Waste Compositions and Atmospheric Dispersion Coefficients for Use in Safety Analysis Consequence Assessments (Van Keuren 1996a). For short duration ground level releases the $<1$ hour $X / Q$ s were used. The reported values are $X / Q^{\prime}=3.41 \mathrm{E}-2 \mathrm{~s} / \mathrm{m}^{3}$ for the onsite receptor (at $100 \mathrm{~m}$ ) and $X / Q^{+}=2.83 E-5 \mathrm{~s} / \mathrm{m}^{3}$ for the offsite receptor (at the site boundary or the near bank of the Columbia River, whichever is closer). Exposures of the onsite and site boundary were calculated using 12hour and 24-hour $X / Q s$, respectively. For release durations intermediate between 2 hours and 1 year $(8760 \mathrm{~h})$, the standard logarithmic averaging formulation was used where the $X / Q^{\prime}$ over a release time of $x$ hours is given by:

$$
\ln \left(\frac{\mathrm{X}}{Q^{\prime}}\right)_{x}=\left[\ln \left(\frac{\mathrm{X}}{Q^{\prime}}\right)_{1 y}-\ln \left(\frac{\mathrm{X}}{Q^{\prime}}\right)_{2 h}\right]\left[\frac{\ln (x)-\ln (2)}{\ln (8760)-\ln (2)}\right]+\ln \left(\frac{\mathrm{X}}{Q^{\prime}}\right)_{2 h}
$$

where it is assumed that the release rate is reasonably constant over the time $x$ hours. The resulting $X / Q$ s are shown in Table 1 .

Table 1: Atmospheric dispersion coefficients $\left(X / Q^{\prime}\right)$

\begin{tabular}{lll} 
Receptor & $\begin{array}{l}\text { Release } \\
\text { Duration }\end{array}$ & $X / Q^{\circ}\left(\mathrm{s} / \mathrm{m}^{3}\right)$ \\
\hline \hline Onsite & $<1 \mathrm{hr}$ & $3.41 \mathrm{E}-2$ \\
& $2 \mathrm{hr}$ & $1.13 \mathrm{E}-2$ \\
$12 \mathrm{hr}$ & $5.54 \mathrm{E}-3$ \\
$1 \mathrm{y}$ & $4.03 \mathrm{E}-4$
\end{tabular}




\begin{tabular}{lrl}
\multicolumn{3}{c}{ HNF-SD-WM-CN-102 } \\
Receptor & $\begin{array}{l}\text { Revease } \\
\text { Duration }\end{array}$ & $X / Q^{\prime}\left(\mathrm{s} / \mathrm{m}^{3}\right)$ \\
\hline \multirow{2}{*}{ 0ffsite } & $<1 \mathrm{hr}$ & $2.83 \mathrm{E}-5$ \\
& $2 \mathrm{hr}$ & $2.12 \mathrm{E}-5$ \\
& $24 \mathrm{hr}$ & $4.62 \mathrm{E}-6$ \\
$1 \mathrm{y}$ & $1.24 \mathrm{E}-7$
\end{tabular}

Note that the $X / Q^{\prime}$ decreases rapidly as receptor distance increases, and also decreases with increasing averaging time (i.e., release duration at a constant rate). A given release will therefore produce more severe consequences if released over a shorter time than if released over a longer time.

Calculations of toxicological consequences for releases considered here assume a continuous release (as opposed to a puff). The appropriate $X / Q$ s are built into the unit release rate sums of fractions (SOF) developed in WHC-SD-WMSARR-011, Toxic Chemical Considerations for Tank Farm Releases (Van Keuren 1996b) and do not need to be handled explicitly here.

\section{Consequence Methodology:}

Radiological and toxicological consequences of releases from the 200 Area Tank Farms were calculated using radiological dose and toxic exposure conversion factors developed in WHC-SD-WM-SARR-037, Development of Radiologica 7 Concentrations and Unit Liter Doses for TWRS FSAR Radiological Consequence Calculations (Cowley 1996) and WHC-SD-WM-SARR-011, Toxic Chemical Considerations for Tank Farm Releases (Van Keuren 1996b). Unit Liter Doses (ULD) for Tanks 241-C-106 and 241-AY-102 solids and liquids are shown in Table 2. These ULDS were taken from WHC-SD-WM-SARR-037 for SST and AWF waste, respectively.

Table 2: Unit Liter Doses (ULD) for Tanks 241-C-106 and 241-AY-102 waste components

$\begin{array}{ll}\text { Inhalation } & \text { Ingestjon } \\ \text { Waste Component } & \mathrm{ULO}(\mathrm{SV} / \mathrm{L})\end{array} \mathrm{ULD}\left(\mathrm{SV} \cdot \mathrm{m}^{3} / \mathrm{s} \cdot \mathrm{L}\right)$

\begin{tabular}{llll}
\hline \hline \multirow{2}{*}{ Tank 241-C-106 Liquids } & $1.1 \mathrm{E}+4$ & $5.2 \mathrm{E}-2$ \\
& Solids & $2.2 \mathrm{E}+5$ & $4.1 \mathrm{E}+0$ \\
Tank 241-AY-102 Liquids & $1.4 \mathrm{E}+3$ & $9.2 \mathrm{E}-2$ \\
& Solids & $1.7 \mathrm{E}+6$ & $8.1 \mathrm{E}+0$
\end{tabular}


Based on the total amounts of solids and liquids in the two tanks, the compositions of the solid and liquid components of the slurry circulating in both directions between tanks $\mathrm{C}-106$ and $\mathrm{AY}-102$ in the sluice line and slurry line have been determined to have the following best estimate compositions:

$$
\begin{aligned}
& \text { Liquids } \Rightarrow 10 \% \text { SST } 1 \text { iquids }+90 \% \text { AWF 1 iquids } \\
& \text { Solids } \Rightarrow 90 \% \text { SST solids }+10 \% \text { AWF solids }
\end{aligned}
$$

The resulting ULDs for the slurry circulating between the two tanks are shown in Table 3 .

Table 3: Unit Liter Doses (ULD) for solid and liquid components of circulating slurry

$\begin{array}{ccc}\text { Slurry } & \text { Inhalation } & \text { Ingestjon } \\ \text { Component } & \operatorname{ULD}(\mathrm{SV} / \mathrm{L}) & \operatorname{ULD}\left(\mathrm{SV} \cdot \mathrm{m}^{3} / \mathrm{s} \cdot \mathrm{L}\right)\end{array}$

$\begin{array}{lll}\text { Liquids } & 2.36 \mathrm{E}+3 & 8.80 \mathrm{E}-2 \\ \text { Solids } & 3.68 \mathrm{E}+5 & 4.50 \mathrm{E}+0\end{array}$

The sluice supernate being pumped from $A Y-102$ to $C-106$ was assumed to be composed of $10 \%$ solids and $90 \%$ liquids, while the slurry being pumped back from $\mathrm{C}-106$ was assumed to be composed of $33 \%$ solids and $67 \%$ Tiquids. The resulting ULDs for the two 1 ines between $\mathrm{C}-106$ and $A Y-102$ are shown in Table 4.

Table 4: Unit Liter Doses (ULD) for sluice supernate from $A Y-102$ and slurry from $\mathrm{C}-106$

$\begin{array}{cc}\text { Transfer } & \text { Inhalation } \\ \text { Line } & \text { ULD }(S V / L)\end{array} \quad$ ULD $\left(S V \cdot \mathrm{m}^{3} / \mathrm{s} \cdot \mathrm{L}\right)$

Sluice Line

from $A Y-102$

$3.89 \mathrm{E}+4$

$5.29 \mathrm{E}-1$

STurry Line

from $\mathrm{C}-106$

$1.23 \mathrm{E}+5$

$1.54 \mathrm{E}+0$

These ULDs were used to calculate onsite and offsite receptor radiological doses using the following formulas. All doses are 50-year committed effective dose equivalents (CEDE). Ingestion doses are for a 24-hour uptake period by the offsite receptor immediately after the passage of the plume assuming a 24 hour delay before evacuation and/or interdiction of food supplies. 
For onsite and offsite inhalation doses:

$$
D_{i n h}=(Q)\left(X / Q^{+}\right)(B R)\left(U L D_{i n h}\right)
$$

And for offsite ingestion doses:

$$
D_{\text {ing }}=(Q)\left(X / Q^{\prime}\right)\left(U L D_{i n g}\right)
$$

Where

$$
\begin{aligned}
& D_{\text {inh }}=\text { inhalation dose (Sv) } \\
& D_{\text {ing }} \text { = ingestion dose (Sv) } \\
& Q^{\text {ing }}=\text { respirable release in terms of } 1 \text { iters of waste material }(L) \\
& X / Q^{\prime}=\text { atmospheric dispersion coefficient }\left(\mathrm{s} / \mathrm{m}^{3}\right) \\
& B R=\text { receptor breathing rate }\left(\mathrm{m}^{3} / \mathrm{s}\right) \\
& \mathrm{ULD}_{\text {inh }}=\text { inhalation unit liter dose }(\mathrm{Sv} / \mathrm{L}) \\
& \text { ULD } D_{\text {ing }}=\text { ingestion unit liter dose }\left(\mathrm{Sv} \cdot \mathrm{m}^{3} / \mathrm{s} \cdot \mathrm{L}\right)
\end{aligned}
$$

For short-duration releases and for 12-hour exposures to the onsite receptor, the light activity breathing rate of $3.3 \mathrm{E}-4 \mathrm{~m} / \mathrm{s}$ was assumed. For 24-hour release exposures to the offsite receptor, the 24 hour average breathing rate of $2.7 \mathrm{E}-4 \mathrm{~m}^{3} / \mathrm{s}$ was assumed.

Toxicological exposure units were developed in WHC-SD-WM-SARR-011 in terms of a sum-of-fractions per unit release rate $(\mathrm{L} / \mathrm{s})$, or per unit release (L) for very short duration (puff) releases. Puff releases are defined in WHC-SD-WMSARR-01l as being releases with durations $\leq 3.5 \mathrm{~s}$ for the onsite receptor or $\leq 250 \mathrm{~s}$ for the site boundary receptor. This parameter already contains the receptor $X / Q^{\prime}$ ( $1 \mathrm{~h}$ or puff) and the chemical component limits associated with a particular accident frequency. The frequency for the spray leak scenarios considered here has been designated as anticipated with a frequency range of 1 - $10^{-2} / y$. Unit release rate sums of fractions for SST and AWF waste given in WHC-SD-WM-SARR-011 for continuous releases are shown in Table 5.

Table 5: Unit release toxicological sums of fractions for SST or AWF waste components for anticipated accident frequency $\left(1-10^{-2} / y\right)$

\begin{tabular}{llll} 
Receptor & Waste Component & $\begin{array}{c}\text { Sum of Fract } \\
(\mathrm{s} / \mathrm{L})\end{array}$ \\
\hline Onsite & Single-Shell Liquids & $\begin{array}{c}9.6 \mathrm{E}+3 \\
\text { Solids }\end{array}$ & $\begin{array}{c}4.0 \mathrm{E}+4 \\
\end{array}$ \\
Offsite & Single-Shel1 Liquids & $\begin{array}{c}8.0 \mathrm{E}+0 \\
\text { Solids }\end{array}$ & $9.4 \mathrm{E}+1$
\end{tabular}

6 of 29 
HNF-SD-WM-CN-102 ReV 0

\begin{tabular}{llll} 
Receptor & Waste Component & $\begin{array}{c}\text { Sum of Fractions } \\
(\mathrm{s} / \mathrm{L})\end{array}$ \\
\hline \hline \multirow{2}{*}{ Onsite } & $\begin{array}{l}\text { Double-Shell Liquids } \\
\text { or AWF }\end{array}$ & $\begin{array}{l}1.0 \mathrm{E}+4 \\
\text { Solids }\end{array}$ & $\begin{array}{l}1.8 \mathrm{E}+4 \\
\text { Offsite }\end{array}$ \\
& $\begin{array}{l}\text { Double-Shel1 Liquids } \\
\text { or AWF }\end{array}$ & $\begin{array}{l}8.4 \mathrm{E}+0 \\
\text { Solids }\end{array}$ & $1.9 \mathrm{E}+2$
\end{tabular}

Given the same solid and liquid component compositions as before, the resulting continuous release SOFs for the slurry circulating between the two tanks are shown in Table 6.

Table 6: Unit release toxicological sums of fractions for liquid and solid slurry components for anticipated accident frequency $\left(1-10^{-2} / y\right)$

Slurry
Receptor $\quad \begin{gathered}\text { Sumpont } \\ (\mathrm{s} / \mathrm{L})\end{gathered}$

\begin{tabular}{lll}
\hline \hline \multirow{2}{*}{ Onsite } & Liquids & $9.96 \mathrm{E}+3$ \\
& Solids & $3.78 \mathrm{E}+4$ \\
Offsite & Liquids & $8.36 \mathrm{E}+0$ \\
& Solids & $1.04 \mathrm{E}+2$
\end{tabular}

The resulting continuous release ULDs for the two 1 ines between $\mathrm{C}-106$ and $\mathrm{AY}$ 102 are shown in Table 7.

Table 7: Unit release toxicological sums of fractions for sluice supernate from $A Y-102$ and slurry from $\mathrm{C}-106$ for anticipated accident frequency

\begin{tabular}{lll} 
Transfer Line & Receptor & $\begin{array}{c}\text { Sum of Fracti } \\
(\mathrm{s} / \mathrm{L})\end{array}$ \\
\hline $\begin{array}{l}\text { Sluice Line } \\
\text { from AY-102 }\end{array}$ & $\begin{array}{l}\text { Onsite } \\
\text { Offsite }\end{array}$ & $\begin{array}{l}1.27+4 \\
1.79+1\end{array}$ \\
$\begin{array}{l}\text { Slurry Line } \\
\text { from C-106 }\end{array}$ & Onsite & $1.91 \mathrm{E}+4$ \\
& & $3.99 \mathrm{E}+1$
\end{tabular}

7 of 29 
HNF-SD-WM-CN-102 Rev 0

Unmitiqated Release Results:

In this case the removable plug over the flush connection has been removed from the pit cover block allowing unimpeded flow vertically into the air. Two sources of aerosolization were evaluated: (1) direct production by edge shear as the slurry flows out of the nozzle and (2) instability/shear stress at the surface of the liquid during the fall from its maximum height and impact on the ground (assumed to be a hard surface). The passage of the falling material through the air creates airflow patterns and turbulence that aids in suspension of the slurry. Both the sluice supernate and slurry return flows were investigated to determine the worst case.

The details of the nozzle spray were modelled using the SPRAY code (Hey and Leach 1994). For the unmitigated case, the orifice was assumed to be a roundedged circular hole with a diameter of 2.067 inches. Note that large leaks with high volume flow rates are less efficient generators of respirable aerosol (i.e., lower respirable fraction), but because of the high flow rate, the total respirable aerosol generation rate tends to have a relatively weak dependence on the size of the leak for large leaks. This type of slurry is a non-Newtonian fluid which could have a viscosity of about 20 cps for shear rates encountered during normal flow in pipes during a transfer. For the high shear rates present in aerosol producing processes, however, a viscosity of 1 cps was assumed consistent with WHC-SD-WM-CN-048. Densities for the soljd and liquid components of the circulating slurry were assumed to be $1.82 \mathrm{~g} / \mathrm{cm}^{3}$ and $1.21 \mathrm{~g} / \mathrm{cm}^{3}$, respectively (Sathyanarayana 1996). The sluice supernate from tank AY-102 (10\% solids) will then have a density of $1.27 \mathrm{~g} / \mathrm{cm}^{3}$ while the slurry from tank C-106 (33\% solids) will have a density of $1.41 \mathrm{~g} / \mathrm{cm}^{3}$.

Care must be taken to correct for evaporation when defining the respirable size fraction of the spray release at the nozzle. A water droplet with an initial diameter $D_{i}$ and a volumetric dissolved or suspended solids fraction $E$ wi11, after evaporation of the water, form a solid partjcle with a final diameter $D_{f}$ approximately related to $D_{i}$ by $D_{i}=\left(D_{f}^{3} / E\right)^{1 / 3}$ (Hey and Leach 1994). The maximum respirable particle size is normally taken to be $10 \mu \mathrm{m}$. This size particle has a gravitational fall velocity (approximately $1 \mathrm{~cm} / \mathrm{s}$ ) about equal to the velocity associated with random vorticity in air. This is, therefore, also about the maximum size particulate which can be transported any distance from a ground level source under low wind speed conditions. For $D_{f}=10 \mu \mathrm{m}$ and $E=0.33, D_{i}$ is $14.5 \mu \mathrm{m}$. The respirable fraction of the nozzle spray for the slurry from tank $C-106$ (33\% solids) is therefore the fraction of aerosol particles with size less than or equal to $14.5 \mu \mathrm{m}$. Similarly, the respirable fraction of the nozzle spray for sluice supernate ( $10 \%$ solids) was based on a maximum diameter of $21.5 \mu \mathrm{m}$.

Parametric analyses were performed using the SPRAY Code (version 3.0, May 3, 1994) (Hey and Leach 1994) to determine upstream pressures within the pipe which matched the estimated liquid velocities at the nozzle and hence the corresponding respirable release rates. The SPRAY code run files for the 
HNF-SD-WM-CN-102 Rev 0

cases matching the nozzle exit velocities are shown in Attachment 3 . The results are shown in Table 8 .

Table 8: Respirable nozzle spray releases for the sluice supernate and slurry return lines

Nozzle Diff. Release 12 Hour 24 Hour Transfer Line Pressure (psig) Rate (L/s) Release (L) Release (L)

\begin{tabular}{lllll}
\hline \hline Sluice Line & 38.0 & $1.74 \mathrm{E}-7$ & $7.52 \mathrm{E}-3$ & $1.50 \mathrm{E}-2$ \\
Slurry Line & 20.5 & $2.08 \mathrm{E}-8$ & $8.99 \mathrm{E}-4$ & $1.80 \mathrm{E}-3$
\end{tabular}

These direct spray releases from the nozzle were negligible compared to the respirable releases produced by the fall and impact of the stream after reaching maximum height above the pit cover. The releases due to the fall and impact will now be treated in detail and the consequences calculated for each of the two slurry types.

$\Rightarrow$ sluice line spray:

The respirable aerosol release produced by the fall and impact of the liquid stream was calculated using methodology recommended in section 3.2.3.1 of DOEHDBK-3010-94 (DOE 1994). Neglecting effects of air resistance, a liquid stream directed vertically upward will attain a height, $h$, given by

$$
h=\frac{1}{2} \frac{v^{2}}{g}
$$

where $v$ is the initial upward velocity and $\mathrm{g}$ is the acceleration due to gravity $\left(32.2 \mathrm{ft} / \mathrm{s}^{2}\right)$. A vertical stream with an initial velocity of $65.3 \mathrm{ft} / \mathrm{s}$ can then reach a height of $66.2 \mathrm{ft}$ or $2.02 \mathrm{E}+3 \mathrm{~cm}$. The airborne release fraction (ARF) of a liquid or slurry falling and impacting on a hard surface from a height $h$ is given by

$$
A R F=8.9 E-10 \operatorname{ArCh}^{0.55}
$$

Arch is the Archimedes Number given by 


\section{HNF-SD-WM-CN-102 Rev 0}

$$
\operatorname{Arch}=\frac{\rho^{2} h^{3} g}{\mu^{2}}
$$

where $\rho$ is the density of air $\left(1.293 \mathrm{E}-3 \mathrm{~g} / \mathrm{cm}^{3}\right), \mathrm{h}$ is the release height (cm), $\mathrm{g}$ is the acceleration due to gravity $\left(981 \mathrm{~cm} / \mathrm{s}^{3}\right)$, and $\mu$ is the liquid viscosity ( $1 \mathrm{E}-2$ poise). The Archimedes Number for this case is then $1.35 \mathrm{E}+11$ leading to an airborne release fraction of $1.18 \mathrm{E}-3$. As recommended in DOEHDBK-3010-94 for this type of release, the respirable fraction (RF) was assumed to be 1 . The resulting respirable release rate is $(41.0 \mathrm{~L} / \mathrm{s})(1.18 \mathrm{E}-3)$ $=4.84 \mathrm{E}-2 \mathrm{~L} / \mathrm{s}$. The corresponding 12 -hour and 24 -hour respirable releases are $2.09 \mathrm{E}+3 \mathrm{~L}$ and $4.18 \mathrm{E}+3 \mathrm{~L}$, respectively.

The onsite receptor inhalation dose was calculated using the 12-hour release and $X / Q^{\prime}$ (from Table 1) as follows. ULDs were taken from Table 4 .

$$
\begin{aligned}
D_{i n h} & =(R)\left(X / Q^{\prime}\right)(B R)(U L D) \\
& =(2.09 E+3 \mathrm{~L})\left(5.54 \mathrm{E}-3 \mathrm{~s} / \mathrm{m}^{3}\right)\left(3.3 \mathrm{E}-4 \mathrm{~m}^{3} / \mathrm{s}\right)(3.89 \mathrm{E}+4 \mathrm{SV} / \mathrm{L}) \\
& =1.49 \mathrm{E}+2 \mathrm{SV}(1.49 \mathrm{E}+4 \mathrm{rem})
\end{aligned}
$$

The offsite dose is the sum of the 24-hour inhalation and ingestion doses as follows. Note that the 24 hour average breathing rate was used for the inhalation dose.

$$
\begin{aligned}
D_{i n h} & =(R)\left(X / Q^{\prime}\right)(B R)(U L D) \\
& =(4.18 E+3 \mathrm{~L})\left(4.62 E-6 \mathrm{~s} / \mathrm{m}^{3}\right)\left(2.7 \mathrm{E}-4 \mathrm{~m}^{3} / \mathrm{s}\right)(3.89 \mathrm{E}+4 \mathrm{~Sv} / \mathrm{L}) \\
& =2.03 \mathrm{E}-1 \mathrm{SV} \\
D_{\text {ing }} & =(R)\left(X / Q^{\prime}\right)(B R)(U L D) \\
& =(4.18 E+3 \mathrm{~L})\left(4.62 \mathrm{E}-6 \mathrm{~s} / \mathrm{m}^{3}\right)\left(5.29 \mathrm{E}-1 \mathrm{SV} \cdot \mathrm{m}^{3} / \mathrm{s} \cdot \mathrm{L}\right) \\
& =1.02 \mathrm{E}-2 \mathrm{SV}
\end{aligned}
$$

Total offsite dose $=2.13 \mathrm{E}-1$ SV $(2.13 \mathrm{E}+1 \mathrm{rem})$

Toxicological Sums of Fractions (SOF) were obtained by multiplying the release rate by the unit release rate SOF from Table 7 as follows.

$$
\begin{aligned}
& \text { Onsite SOF }=(4.84 \mathrm{E}-2 \mathrm{~L} / \mathrm{s})(1.27 \mathrm{E}+4 \mathrm{~s} / \mathrm{L}) \\
&=6.15 \mathrm{E}+2 \\
& \begin{aligned}
\text { Offsite SOF } & =(4.84 \mathrm{E}-2 \mathrm{~L} / \mathrm{s})(1.79 \mathrm{E}+1 \mathrm{~s} / \mathrm{L}) \\
& =8.66 \mathrm{E}-1
\end{aligned}
\end{aligned}
$$


$\Rightarrow$ slurry line spray:

A vertical stream with an initial velocity of $45.2 \mathrm{ft} / \mathrm{s}$ can then reach a height of $31.7 \mathrm{ft}$ or $9.67 \mathrm{E}+2 \mathrm{~cm}$. The Archimedes Number for this case is then $1.48 \mathrm{E}+10$ leading to an airborne release fraction of $3.49 \mathrm{E}-4$. As recommended in DOE-HDBK-3010-94 for this type of release, the respirable fraction (RF) was assumed to be 1 . The resulting respirable release rate is $(28.4 \mathrm{~L} / \mathrm{s})(3.49 \mathrm{E}-4)$ $=9.92 \mathrm{E}-3 \mathrm{~L} / \mathrm{s}$. The corresponding 12-hour and 24-hour respirable releases are $4.28 \mathrm{E}+2 \mathrm{~L}$ and $8.57 \mathrm{E}+2 \mathrm{~L}$, respectively.

The onsite receptor inhalation dose was calculated using the 12-hour release and $X / Q^{\prime}$ (from Table 1) as follows. ULDs were taken from Table 4.

$$
\begin{aligned}
D_{i n h} & =(R)\left(X / Q^{\prime}\right)(B R)(U L D) \\
& =(4.28 E+2 L)\left(5.54 \mathrm{E}-3 \mathrm{~s} / \mathrm{m}^{3}\right)\left(3.3 \mathrm{E}-4 \mathrm{~m}^{3} / \mathrm{s}\right)(1.23 \mathrm{E}+5 \mathrm{sv} / \mathrm{L}) \\
& =9.62 \mathrm{E}+1 \mathrm{~Sv}(9.62 \mathrm{E}+3 \mathrm{rem})
\end{aligned}
$$

The offsite dose is the sum of the 24-hour inhalation and ingestion doses as follows. Note that the 24 hour average breathing rate was used for the inhalation dose.

$$
\begin{aligned}
& D_{\text {inh }}=(R)\left(X / Q^{\prime}\right)(B R)(U L D) \\
&=(8.57 \mathrm{E}+2 \mathrm{~L})\left(4.62 \mathrm{E}-6 \mathrm{~s} / \mathrm{m}^{3}\right)\left(2.7 \mathrm{E}-4 \mathrm{~m}^{3} / \mathrm{s}\right)(1.23 \mathrm{E}+5 \mathrm{~Sv} / \mathrm{L}) \\
&=1.31 \mathrm{E}-1 \mathrm{SV} \\
& D_{\text {ing }}=(R)\left(X / Q^{\prime}\right)(B R)(U L D) \\
&=(8.57 \mathrm{E}+2 \mathrm{~L})\left(4.62 \mathrm{E}-6 \mathrm{~s} / \mathrm{m}^{3}\right)\left(1.54 \mathrm{E}+0 \mathrm{~Sv} \cdot \mathrm{m}^{3} / \mathrm{s} \cdot \mathrm{L}\right) \\
&=6.10 \mathrm{E}-3 \mathrm{SV} \\
& \text { Total offsite dose }=1.38 \mathrm{E}-1 \mathrm{SV}(1.38 \mathrm{E}+1 \mathrm{rem})
\end{aligned}
$$

Toxicological Sums of Fractions (SOF) were obtained by multiplying the release rate by the unit release rate SOF from Table 7 as follows.

$$
\begin{aligned}
\text { Onsite SOF } & =(9.92 \mathrm{E}-3 \mathrm{~L} / \mathrm{s})(1.91 \mathrm{E}+4 \mathrm{~s} / \mathrm{L}) \\
& =1.89 \mathrm{E}+2 \\
\text { Offsite SOF } & =(9.92 \mathrm{E}-3 \mathrm{~L} / \mathrm{s})(3.99 \mathrm{E}+1 \mathrm{~s} / \mathrm{L}) \\
& =3.96 \mathrm{E}-1
\end{aligned}
$$

\section{Mitigated Release Results:}

In this case the removable plug over the flush connection remains in place confining the slurry stream from the flush connection to the pit. This is the only change from the unmitigated release case. It was assumed (consistent

$$
11 \text { of } 29
$$




\section{HNF-SD-WM-CN-102 Rev 0}

with WHC-SD-WM-CN-048) that the impact of the stream on the underside of the pit cover saturates the air within the pit to the maximum sustainable air loading of $100 \mathrm{mg} / \mathrm{m}^{3}$ (ANSI N46.1 1980). The direct aerosol release is then carried with the air displaced from the pit while it fills with slurry. No credit is taken in this bounding analysis for either the leak detectors or the 6 -inch high capacity drains in the pits. This direct release will now be evaluated in detail for the two slurry types. Note that once the pit fills and overflows, the slurry will form a pool on the ground above. The releases from such a pool are beyond the scope of this analysis and will be treated el sewhere.

$\Rightarrow$ sluice line spray:

The sluice line flush connection is in pit 24l-AY-02E with inside dimensions of $8 \mathrm{ft} \times 6 \mathrm{ft} \times 7 \mathrm{ft}$ (see Attachment 2) giving an interior volume of $336 \mathrm{ft}^{3}$ or $9.5 \mathrm{~m}^{3}$. The total volume displaced while the pit is filling with slurry is this volume plus an additional $35 \%$ due to heating of the air in the pit and addition of water vapor up to $100 \%$ R.H. (Hall 1996). The total air volume displaced out of the pit through crevices and small openings is then $12.8 \mathrm{~m}^{3}$ implying a slurry aerosol release of $1.28 \mathrm{~g}$. Using the sluice supernate densjty, the equivalent slurry volume can be calculated as $(1.28 \mathrm{~g}) /(1.27$ $\left.\mathrm{g} / \mathrm{cm}^{3}\right)=1.01 \mathrm{~cm}^{3}$ or $1.01 \mathrm{E}-3 \mathrm{~L}$. At a slurry addition rate of $41.0 \mathrm{~L} / \mathrm{s}$ or $4.10 \mathrm{E}-2 \mathrm{~m}^{3} / \mathrm{s}$, the pit will $\mathrm{fill}$ in $232 \mathrm{~s}$ or 3.86 minutes. Note that no credit was taken for volume taken up by piping and machinery within the pit. The slurry aerosol release rate due to volume displacement is then $(1.01 \mathrm{E}-3$ $\mathrm{L}) /(232 \mathrm{~s})=4.35 \mathrm{E}-6 \mathrm{~L} / \mathrm{s}$.

The onsite receptor inhalation dose was calculated using the $<1$-hour release and $X / Q^{\prime}$ (from Table 1) as follows. ULDs were taken from Table 4.

$$
\begin{aligned}
D_{i n h} & =(R)\left(X / Q^{\prime}\right)(B R)(U L D) \\
& =(1.01 E-3 \mathrm{~L})\left(3.41 \mathrm{E}-2 \mathrm{~s} / \mathrm{m}^{3}\right)\left(3.3 \mathrm{E}-4 \mathrm{~m}^{3} / \mathrm{s}\right)(3.89 \mathrm{E}+4 \mathrm{SV} / \mathrm{L}) \\
& =4.42 \mathrm{E}-4 \mathrm{SV}(4.42 \mathrm{E}-2 \mathrm{rem})
\end{aligned}
$$

The offsite dose is the sum of the inhalation and ingestion doses as follows. Note that the $<1$-hour $X / Q^{\prime}$ and the light activity breathing rate was used due to the short release duration.

$$
\begin{aligned}
& D_{\text {inh }}=(R)\left(X / Q^{\prime}\right)(B R) \text { (ULD) } \\
& =(1.01 \mathrm{E}-3 \mathrm{~L})\left(2.83 \mathrm{E}-5 \mathrm{~s} / \mathrm{m}^{3}\right)\left(3.3 \mathrm{E}-4 \mathrm{~m}^{3} / \mathrm{s}\right)(3.89 \mathrm{E}+4 \mathrm{SV} / \mathrm{L}) \\
& =3.67 \mathrm{E}-7 \mathrm{SV} \\
& D_{\text {ing }}=(R)\left(X / Q^{+}\right)(B R)(U L D) \\
& =(1.01 \mathrm{E}-3 \mathrm{~L})\left(2.83 \mathrm{E}-5 \mathrm{~s} / \mathrm{m}^{3}\right)\left(5.29 \mathrm{E}-1 \mathrm{SV} \cdot \mathrm{m}^{3} / \mathrm{s} \cdot \mathrm{L}\right) \\
& =1.51 \mathrm{E}-8 \mathrm{SV} \\
& \text { Total offsite dose }=3.82 \mathrm{E}-7 \mathrm{~Sv}(3.82 \mathrm{E}-5 \mathrm{rem})
\end{aligned}
$$


Toxicological Sums of Fractions (SOF) were obtained by multiplying the release rate by the unit release rate SOF from Table 7 as follows.

$$
\begin{aligned}
\text { Onsite SOF } & =(4.35 \mathrm{E}-6 \mathrm{~L} / \mathrm{s})(1.27 \mathrm{E}+4 \mathrm{~s} / \mathrm{L}) \\
& =5.53 \mathrm{E}-2 \\
\text { Offsite SOF } & =(4.35 \mathrm{E}-6 \mathrm{~L} / \mathrm{s})(1.79 \mathrm{E}+1 \mathrm{~s} / \mathrm{L}) \\
& =7.79 \mathrm{E}-5
\end{aligned}
$$

$\Rightarrow$ slurry line spray:

The slurry line flush connection is in pit 241-AY-02A with inside dimensions of $12 \mathrm{ft} \times 8 \mathrm{ft} \times 5 \mathrm{ft}$ (see Attachment 2) giving an interior volume of $480 \mathrm{ft}^{3}$ or $13.6 \mathrm{~m}^{3}$. The total volume displaced while the pit is filling with slurry is this volume plus an additional $35 \%$ due to heating of the air in the pit and addition of water vapor up to $100 \%$ R.H. (Hall 1996). The total air volume displaced out of the pit through crevices and small openings is then $18.4 \mathrm{~m}^{3}$ implying a slurry aerosol release of $1.84 \mathrm{~g}$. Using the return slurry density, the equivalent slurry volume can be calculated as $(1.84 \mathrm{~g}) /\left(1.41 \mathrm{~g} / \mathrm{cm}^{3}\right)=1.30$ $\mathrm{cm}^{3}$ or $1.30 \mathrm{E}-3 \mathrm{~L}$. At a slurry addition rate of $28.4 \mathrm{~L} / \mathrm{s}$ or $2.84 \mathrm{E}-2 \mathrm{~m}^{3} / \mathrm{s}$, the pit will fill in $479 \mathrm{~s}$ or 7.98 minutes. Note that no credit was taken for volume taken up by piping and machinery within the pit. The slurry aerosol release rate due to volume displacement is then $(1.30 \mathrm{E}-3 \mathrm{~L}) /(479 \mathrm{~s})=2.71 \mathrm{E}-6$ $\mathrm{L} / \mathrm{s}$.

The onsite receptor inhalation dose was calculated using the $<1$-hour release and $X / Q^{\prime}$ (from Table 1) as follows. ULDs were taken from Table 4.

$$
\begin{aligned}
D_{i n h} & =(R)\left(X / Q^{\prime}\right)(B R)(U L D) \\
& =(1.30 E-3 \mathrm{~L})\left(3.41 \mathrm{E}-2 \mathrm{~s} / \mathrm{m}^{3}\right)\left(3.3 \mathrm{E}-4 \mathrm{~m}^{3} / \mathrm{s}\right)(1.23 \mathrm{E}+5 \mathrm{sV} / \mathrm{L}) \\
& =1.80 \mathrm{E}-3 \mathrm{SV}(1.80 \mathrm{E}-1 \mathrm{rem})
\end{aligned}
$$

The offsite dose is the sum of the inhalation and ingestion doses as follows. Note that the $<1$-hour $X / Q^{\prime}$ and the light activity breathing rate was used due to the short release duration.

$$
\begin{aligned}
& \mathrm{D}_{\text {inh }}=(\mathrm{R})\left(\mathrm{X} / \mathrm{Q}^{\prime}\right)(\mathrm{BR})(\mathrm{ULD}) \\
& =(1.30 \mathrm{E}-3 \mathrm{~L})\left(2.83 \mathrm{E}-5 \mathrm{~s} / \mathrm{m}^{3}\right)\left(3.3 \mathrm{E}-4 \mathrm{~m}^{3} / \mathrm{s}\right)(1.23 \mathrm{E}+5 \mathrm{SV} / \mathrm{L}) \\
& =1.49 \mathrm{E}-6 \mathrm{SV} \\
& D_{\text {ing }}=(R)\left(X / Q^{\prime}\right)(B R)(U L D) \\
& =(1.30 \mathrm{E}-3 \mathrm{~L})\left(2.83 \mathrm{E}-5 \mathrm{~s} / \mathrm{m}^{3}\right)\left(1.54 \mathrm{E}+0 \mathrm{sV} \cdot \mathrm{m}^{3} / \mathrm{s} \cdot \mathrm{L}\right) \\
& =5.67 \mathrm{E}-8 \mathrm{SV} \\
& \text { Total offsite dose }=1.55 \mathrm{E}-6 \mathrm{SV}(1.55 \mathrm{E}-4 \mathrm{rem})
\end{aligned}
$$


HNF-SD-WM-CN-102 Rev 0

Toxicological Sums of Fractions (SOF) were obtained by multiplying the release rate by the unit release rate SOF from Table 7 as follows.

$$
\begin{aligned}
\text { Onsite sOF } & =(2.71 \mathrm{E}-6 \mathrm{~L} / \mathrm{s})(1.91 \mathrm{E}+4 \mathrm{~s} / \mathrm{L}) \\
& =5.18 \mathrm{E}-2 \\
\text { Offsite SOF } & =(2.71 \mathrm{E}-6 \mathrm{~L} / \mathrm{s})(3.99 \mathrm{E}+1 \mathrm{~s} / \mathrm{L}) \\
& =1.08 \mathrm{E}-4
\end{aligned}
$$

\section{Conclusion:}

The results of the two flush connection spray leak cases are summarized in Tables 9 through 12 .

Table 9: Consequences of unmitigated sluice line spray

$\begin{array}{clcc}\text { Hazard } & \text { Receptor } & \text { Dose/Exposure } & \begin{array}{c}\text { Evaluation Guideline } \\ \text { (anticipated) }\end{array} \\ \text { Radiological } & \begin{array}{l}\text { Offsite } \\ \text { Onsite }\end{array} & \begin{array}{l}210 \mathrm{mSV} \\ 150 \mathrm{SV}\end{array} & \begin{array}{l}1 \mathrm{mSV} \\ 5 \mathrm{mSv}\end{array} \\ \text { Toxicological } & \begin{array}{l}\text { Offsite } \\ \text { Onsite }\end{array} & \begin{array}{l}8.7 \mathrm{E}-1 \\ 6.2 \mathrm{E}+2\end{array} & 1\end{array}$

Table 10: Consequences of unmitigated slurry line spray

\begin{tabular}{cccc} 
Hazard & Receptor & Dose/Exposure & $\begin{array}{c}\text { Evaluation Guideline } \\
\text { (anticipated) }\end{array}$ \\
\hline Radiological & $\begin{array}{l}\text { Offsite } \\
\text { Onsite }\end{array}$ & $\begin{array}{c}140 \mathrm{mSv} \\
96 \mathrm{~Sv}\end{array}$ & $\begin{array}{c}1 \mathrm{mSv} \\
\mathbf{m S v}\end{array}$ \\
Toxicological & $\begin{array}{l}\text { Offsite } \\
\text { Onsite }\end{array}$ & $\begin{array}{c}4.0 \mathrm{E}-1 \\
1.9 \mathrm{E}+2\end{array}$ & 1
\end{tabular}

Between the unmitigated cases (cover block plug removed), the sluice line spray (Table 9) is more limiting due to the higher flow rate out of the flush connection and the greater height (and therefore fall distance) reached by the stream. This is due mainly to the proximity of the leak to the sluice pump. 
HNF-SD-WM-CN-102 Rev 0

Table 11: Consequences of mitigated sluice line spray

\begin{tabular}{|c|c|c|c|}
\hline Hazard & Receptor & Dose/Exposure & $\begin{array}{l}\text { Evaluation Guidel ine } \\
\quad \text { (anticipated) }\end{array}$ \\
\hline Radiological & $\begin{array}{l}\text { Offsite } \\
\text { Onsite }\end{array}$ & $\begin{array}{c}0.00038 \mathrm{mSv} \\
0.44 \mathrm{mSv}\end{array}$ & $\begin{array}{l}1 \mathrm{mSv} \\
5 \mathrm{mSv}\end{array}$ \\
\hline Toxicological & $\begin{array}{l}\text { Offsite } \\
\text { Onsite }\end{array}$ & $\begin{array}{l}7.8 \mathrm{E}-5 \\
5.5 \mathrm{E}-2\end{array}$ & $\begin{array}{l}1 \\
1\end{array}$ \\
\hline
\end{tabular}

Table 12: Consequences of mitigated slurry line spray

Hazard Receptor Dose/Exposure $\begin{gathered}\text { Evaluation Guideline } \\ \text { (anticipated) }\end{gathered}$

\begin{tabular}{llcc}
\hline \hline Radiological & $\begin{array}{l}\text { Offsite } \\
\text { Onsite }\end{array}$ & $\begin{array}{c}0.0016 \mathrm{mSv} \\
1.8 \mathrm{mSv}\end{array}$ & $\begin{array}{c}1 \mathrm{mSv} \\
\text { Toxicological }\end{array}$ \\
$\begin{array}{l}\text { Offsite } \\
\text { Onsite }\end{array}$ & $1.1 \mathrm{E}-4$ & 1 \\
& $5.2 \mathrm{E}-2$ & 1
\end{tabular}

Between the two mitigated cases (cover block plug in place), the slurry return line (Table 12) is more limiting due to higher solids content of the slurry and hence higher ULDS and unit release rate SOFs. For the mitigated case a11 consequences are well within guidelines and so no additional controls are needed beyond the existing control of having all pit covers and removable plugs in place during any waste transfer. The consequences shown in Table 12 do not include releases from the above-ground pool which would form once the pit fills with slurry. The analysis of such releases is beyond the scope of this document and are considered in a separate analysis.

In this analysis it is assumed that the slurry distributor above the sludge Tevel in AY-102 is functioning so as to discharge the slurry in four horizontal directions as $p l a n n e d$. If the slurry distributor were to come off the end of the slurry line from $\mathrm{C}-106$, the effect (at least near the beginning of the operation) could be to mix a large amount of AY-102 slurry with the sluice liquid going to $C-106$. As a worst case, it could be assumed that the sluice liquid carries 33\% AWF solids and $67 \%$ AWF liquids. This change would increase the ULDs and SOFs for the sluice liquid. The offsite toxicologica? SOF in Table 10 for the sluice line spray without controls would increase from 0.42 to about 1.6 which would not change any conclusions since the radiological dose is already above the guidelines. The onsite radiological dose for the mitigated sluice line spray shown in Table 11, however would

$$
15 \text { of } 29
$$




\section{HNF-SD-WM-CN-102 Rev 0}

increase from $0.44 \mathrm{mSv}$ to about $6.3 \mathrm{mSv}$. This would put the onsite consequences of the mitigated sluice line spray leak slightly above risk guideline of $5 \mathrm{mSv}$ for an accident in the "anticipated" frequency class. All other consequences of the mitigated accident would remain below guidelines. (Note that it could be argued that the spray leak plus failure of the slurry distributor would be in the "unlikely" frequency category.)

Note that both pits are equipped with leak detectors and high capacity 6-inch drains for which no credit is claimed in this bounding analysis. Either one of these additional features would, in reality, reduce the consequences of the mitigated spray release to a small fraction of those shown in Table 12 , and, in addition, would prevent any overflow from the pit and formation of an above-ground pool.

\section{References:}

ANSI N46.1, 1980, American National Standard - Guidance for Defining SafetyRelated Features of Nuclear Fuel Cycle Facilities, American Nuclear Society, La Grange Park, I1linois.

Cowley 1996, W.L. Cowley, Development of Radiological Concentrations and Unit Liter Doses for TWRS FSAR Radiological Consequence Calculations, WHC-SDWM-SARR-037, ApriT 1996.

DOE 1994, DOE Handbook - Airborne Release Fractions/Rates and Respirable Fractions for Nonreactor Nuclear Facilities, DOE-HDBK-3010-94, December 1994.

Hall 1996, B.W. Hal1, Calculation Notes in Support of TWRS FSAR Spray Leak Accident Analysis, WHC-SD-WM-CN-048 Rev 1, September 1996.

Hey and Leach 1994, B.E. Hey and D.S. Leach, A Model for Predicting Respirable Releases from Pressurized Leaks, WHC-SD-GN-SWD-20007 Rev 0, Apri1 1994.

Himes 1997, D.A. Himes, Refined Radiological and Toxicological Consequences of Bounding Spray Leak Accidents in Tank Farm Waste Transfer Pits, HNF-SDWM-CN-096 Rev 0, February 1997.

Sathyanarayana 1996, K. Sathyanarayana, Evaluation of Potential and Consequences of Steam Bump in High Heat Waste Tanks and Assessment and Validation of GOTH Computer Code, WHC-SD-WM-CN-022 Rev 0, July 1996.

Van Keuren 1996a, J.C. Van Keuren, Tank Waste Compositions and Atmospheric Dispersion Coefficients for use in Safety Analysis Consequence Assessments, WHC-SD-WM-SARR-016 Rev 2, July 1996.

Van Keuren 1996b, J.C. Keuren, J.S. Davis, and M.L. Dentler, Toxic Chemical Considerations for Tank Farm Releases, WHC-SD-WM-SARR-011 Rev 2, July 1996. 
HNF-SD-WM-CN-102 Rev 0

\section{Attachment 1 \\ Analysis of Flushing Nozzle Lifting Force by $W-320$ Design Staff}


KAISER ENGINEERS

$$
\text { HNF-SD-WM-CN-102 Rev } 0
$$

Canc. No. $2320-27 \cdot 046$

DESIGN ANALYSIS

Revision $\frac{0}{1}$ of 2

Client Numatec Hanford Corporation

WO/Job No. EOQ914Z/P2XYOI

Subject Flushing Nozzle Lifting Force Date $3 / 11 / 97$ By $\overline{\alpha K}$ Peterson

Location $241-A y-102$ onE Sluice Pit Revised

By

This calculation is to support USQ TF-97-0214 an ECN w320-587 The goals to show a potential accident scenario, of not blanking off the flushing nozzle after flushing the sluice line, will not dislodge the cover black plug directly above the nozzle.

Assume that the velocity does not significantly change between the nozzle and just prior to striking the bottom of the plug. Also, assume that the fluid stream does rot significantly. widen in diameter from the nozzle exit to striking the bottom face of the plug. Assume the maximum flow rate from the inline pump is $080 \mathrm{gpm}$ for the worst case. Assume worst case is for 10\% solids with a specific gravity of 1.12. Assume all fluid is being pumped through the nozzle.

The calculation will use the formula for an open jet on a horizontal flat plate and compare the resultant fire with the weight of the cover block plug.

References:

(1) H-2-818454, sheet 3 , Detail 8

(2) H-2-81850I, sheet 1

(3) H-2-818 503 , Sliest I

(4) HNF-SD-W320-FDC-001, Rev.4, Sect. 2.2 .2

(5) Vendor Data: Lawrence Pumps Inc, Vertical Inline, RPm 3056 , Item P.:

(6) Lawrence Pumps Inc, Submersible/ Slurry, RPM 1760, Item P-136,

(7) Mechanical Engineering Reference Manual, 8 $8^{\text {th }}$ ed, Michael Lindeburg, p. 3-29

(8) $H-2-818544$, sheet 2

Conclusion:

The force developed in the worst case situation $(2 / 2 / 6)$ is not sufficient to lift the cover block plug $(350 \mathrm{lb})$.

18 of 29

ค G.P.O. $689-996 \quad 12 / 96$ 
KAISER ENGINEERS
HANFORD

$$
\text { HNF-SD-WM-CN-102 Rev } 0
$$

Cain. No. $13220 \cdot 27 \cdot 046$

DESIGN ANALYSIS

Revision $\frac{0}{2}$ of 2

Client Numatec Hanford Corporation

wo/sob No. E09/47/P2XYo

Subject Flashing Nozzle Lit ting Force

Date 3/11/97 By TK Peterson

Location 24/-AY-102 O2E Sluice Pit

Revised

By

Coveriblock plug weight $=350$

Ref. I

$\dot{Q}=680 \mathrm{gpm}$, maximum

Ref. $5+6$

Nozzle is $2 " \varnothing$ schedule $40,21 / 6$ "ID

Ref. $2+3$

specific gravity, $S_{p} G=1.12$. for $10 \%$ solids Ref. 4

16 " from nozzle to bottom face of plug

Ref. 8

$$
\begin{aligned}
& F=\left(\frac{\dot{V}_{\rho}}{g_{c}}\right) \sqrt{v_{0}^{2}-2 g h} \\
& p=(1.12)\left(62.4 \mathrm{~b} / \mathrm{ft}^{3}\right) \\
& \overbrace{\prod^{n} \cdot a}^{l^{F}} \\
& \rho=69.888 \mathrm{lb} / \mathrm{ft}^{3} \\
& g=32.2 \mathrm{ft} / \mathrm{s}^{2} \quad g_{c}=322 \frac{\mathrm{kbm} \cdot \mathrm{fr}}{16 \mathrm{f} \cdot \mathrm{s}^{2}} \\
& h=1.33 \mathrm{ft} \\
& \dot{V}=(680 \mathrm{gpm})\left(0.00222 \frac{\mathrm{ft}^{3} / \mathrm{s}}{\mathrm{gpm}^{\mathrm{m}}}\right)=1.515 \mathrm{ft} / \mathrm{s} \\
& v_{0}=\frac{1.515 \mathrm{ft}^{3} / \mathrm{s}}{\left(\frac{2.0625 \mathrm{in}}{2(12 \mathrm{in} / \mathrm{tt})}\right)^{2} \pi}=65.3 \mathrm{ft} / \mathrm{s} \\
& F=\left(\frac{\left(1.515 \mathrm{ft}^{3} / \mathrm{s}\right)\left(69.888 \mathrm{lbm} / \mathrm{ft}^{3}\right)}{32.2 \frac{\mathrm{f}-1 \mathrm{bm}}{16 \mathrm{f}}}\right) \sqrt{(65.3 \mathrm{ft} / \mathrm{s})^{2}-2(32.2 \mathrm{ft} / \mathrm{s})(1.33 \mathrm{ft})} \\
& F=212.55 \mathrm{lbf} \text { of lift }<350 \mathrm{lb} \text { of plug weight }
\end{aligned}
$$

Ref. 7

Ar G.P.O. $689-996 \quad 12 / 94$ 
HNF-SD-WM-CN-102 Rev 0

Attachment 2

Additional Information from W-320 Design Staff

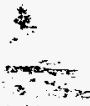


[7] From: John C Conner at HANFORD02B 3/24/97 3:25PM (2208 bytes: 1 ln) Priority: Urgent

To: Steven E Chalk at $B C S 4$, Brit E Hey, John C Van Keuren at ־ANFORDO2D, Rick J Van Vleet at -HANFORD02D, David A Himes

Receipt Requested

Subject: Fountain Flow from 2" Flush Connection

From: Danny L Evans at KEH10 3/24/97 12:49PM (1448 bytes: 17 In)

To: John C Conner at HANFORDO2B

CC: John W Bailey at HANFORD10C, Kerry E Albin at HANFORDIOB,

Susan K Farnworth at HANFORDO7E, Danny L Evans, Theresa K Peterson at

"HANFORDO7E

Subject: Fountain Flow from 2" Flush Connection

Forwarded for you attention on the spray leak scenario.

John C.

Forward Header

Subject: Fountain flow from 2" Flush Connection

Author: Danny L Evans at “KEH1O

Date: $\quad 3 / 24 / 97 \quad 12: 49$ PM

W-320's design staff has completed a caiculation, W320-27-046, examining the lift resulting from an open flush connection in the AY-Farm pits. The worst case scenario is, the 2" flush connector falls off the sluice line in the AY-Farm sluice pit. This leads to an open 2" pipe, a few feet from the discharge of the sluice line booster pump. The booster pump sees no discharge head and immediately jumps to $650 \mathrm{gpm}$, if running at $3,056 \mathrm{rpm}$.

The opening is a 2" pipe, ID 2.067", the pressure above the opening is atmospheric pressure 14.4 psia, the discharge velocity is $65.3 \mathrm{ft} / \mathrm{sec}$, and the upward force on the $350 \mathrm{ib}$ shield plug is $212.51 \mathrm{bf}$.

The shield plug will remain in place. Various instruments would report this anomaly and the operators would immediately stop sluicing. 
[9] From: Danny L Evans at KEH10 3/28/97 9:05AM (2163 bytes: 46 ln)

To: David A Himes at HANFORDO2B

cc: Danny L Evans

Subject: $W-320$ spray leak

Forwarded with Changes

From: David A Himes at “HANFORD02B 3/27/97 1:32PM (896 bytes: 17 in)

To: Danny L Evans at KEHIO

Subject: $W-320$ spray leak

$\mathrm{Hi}$ - it's me again. had a few more questions and haven't

received the copy of your analysis of the open flush

connection yet.

Timing was bad; however, the calc was in the mail, Wendesday.

1. you indicated (I think) that the flush connections for both the sluice line and the slurry line were up near

AY-102. Is this right?

Correct, both the sluice line and slurry line fluxh connections are in pit atop AY-102.

2. Are both flush connections in the same pit or different pits? Can you give me the pit number(s)?

The sluice line flush connection is in the Sluice Pit (241-AY-02E).

The slurry line flush connection is in the Pump Pit

(241-AY-02A)

3. What is the approximate volume of the pit(s)

involved. (inside or outside dimensions would be fine.)

The inside pit dimensions are $(w, 1, h)$ :

$02 A$, Pump Pit, $12^{\prime} \times 8^{\prime} \times 5^{\prime}$

02E, Sluice Pit, $8^{\prime} \times 6^{\prime} \times 7^{\prime}$

Both pits include high capacity drains (6" diameter holes)

in the base plates of installed equipment. The high capacity drains are approx. 1" to 4 " above the pit low points and return liquids to AY-102. The pit low points

include leak detectors and sump pumps to return small leak volumns to $A Y-102$.

Have a nice day.

Dave

Working on one.

Dan

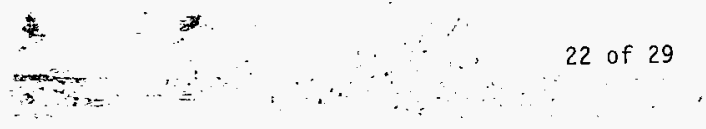


HNF-SD-WM-CN-102 Rev 0

Attachment 3 SPRAY Code Runfiles 
HNF-SD-WM-CN-102 Rev 0

SPRAY Version 3.0

May 3, 1994

Spray Leak Code

Produced by Radiological \& Toxicological Analysis

Westinghouse Hanford Company

Run Date $=03 / 25 / 97 /$

Run Time $=12: 56: 26.97$

INPUT ECHO:

c $10 \%$ solids sluice line spray - 2 inch pipe

c SPRAY Version 3 Input Deck

c mode iflow iopt

$\begin{array}{lll}1 & 0 & \mathrm{~F}\end{array}$

C

c MODEL OPTIONS:

$c$ mode $=1$ then orifice leak with friction assumed

c 2 then slit leak with friction assumed

c iflow $=0$ Reynold's number determines friction relation (i.e. laminar or turb.

c $\quad=1$ friction based on laminar relation

c $\quad=2$ friction based on turbulent relation

c iopt $=\mathrm{T}$ then optimal diameter search performed

$c \quad=F$ then no optimal search

c

c PARAMETER INPUT:

C

c Initial slit

Width or Slit

Orifice Dia. Length

c (in) (in)

c

$\overline{2.06700 \mathrm{E}+00} \overline{0.00000 \mathrm{E}+00} \quad \overline{1.00000 \mathrm{E}+00}$

c

c

C

C

c

C

c

c

c

c

Absolute

Surface

Roughness

(in)

S1it or

Orifice

Depth

(in)

Pressure

0.00006 tube

Contraction

Coefficient

Velocity

Differential

0.0018

0.61

and

Coefficient

(psi)

0.0102 iron

1.00

and

0.98 for sharp edge orifice

0.98 for rounded orifice

$3.80000 E+01$

$\overline{1.80000 \mathrm{E}-03}$

$\overline{1.00000 E+00}$

0.82 for square edge orifice 


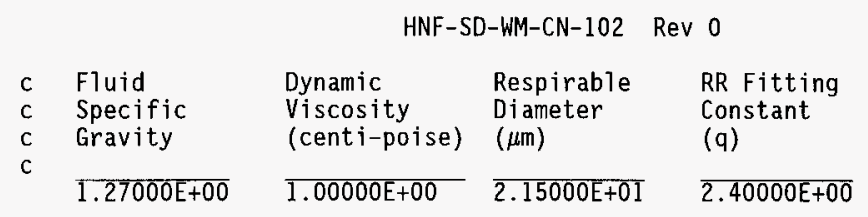

MESSAGES:

Orifice Model

User specified orifice diameter or slit width.

OUTPUT:

Liquid Velocity $=6.50 \mathrm{E}+01 \mathrm{ft} / \mathrm{s} \quad 1.98 \mathrm{E}+01 \mathrm{~m} / \mathrm{s}$

Reynolds Number $=1.32 \mathrm{E}+06$ Turbulent Flow

Sauter Mean Diameter $=4.42 \mathrm{E}+04 \mu \mathrm{m}$

Respirable Fraction $=4.05 \mathrm{E}-09$

Tota1 Leak Rate $=6.80 \mathrm{E}+02 \mathrm{gpm}$

Respirable Leak Rate $=2.76 \mathrm{E}-06 \mathrm{gpm}$

4. $29 \mathrm{E}-02 \mathrm{~m} 3 / \mathrm{s}$

$1.74 \mathrm{E}-10 \mathrm{~m} 3 / \mathrm{s}$

$5.45 \mathrm{E}+04 \mathrm{~g} / \mathrm{s}$

$2.21 \mathrm{E}-04 \mathrm{~g} / \mathrm{s}$ 
HNF-SD-WM-CN-102 Rev 0

SPRAY Version 3.0

May 3, 1994

\begin{abstract}
Spray Leak Code
Produced by Radiological \& Toxicological Analysis

Westinghouse Hanford Company
\end{abstract}

Run Date $=03 / 26 / 97 /$

Run Time $=11: 12: 19.14$

INPUT ECHO:

c $33 \%$ solids slurry line spray - 2 inch pipe

c SPRAY Version 3 Input Deck

c mode iflow iopt

c

c MODEL OPTIONS:

$c$ mode $=1$ then orifice leak with friction assumed

c 2 then slit leak with friction assumed

c iflow= 0 Reynold's number determines friction relation (i.e. laminar or turb.

$\mathrm{c} \quad=1$ friction based on laminar relation

c $\quad=2$ friction based on turbulent relation

$c$ iopt $=T$ then optimal diameter search performed

c $=F$ then no optimal search

c

c PARAMETER INPUT:

c

c Initial S1it

c

C

C

c

Width or S1it

Orifice Dia.

(in)

Length

Slit or

(in)

(in)

Orifice

Depth

$\overline{2.06700 \mathrm{E}+00}$

$\overline{0.00000 \mathrm{E}+00}$

$c$

c

c

c

c

C

C

c

c

Absolute

Surface

Roughness

Contraction

Coefficient

Pressure

(in)

$\overline{1.00000 E+00}$

Differential

0.00006 tube 0.61

and

0.0018 steel 1.00

and

(psi)

0.0102 iron 1.00 and

Velocity

Coefficient

$\overline{2.05000 \mathrm{E}+01}$

$\overline{1.80000 E-03}$

$\overline{1.00000 \mathrm{E}+00}$

0.98 for sharp edge orifice

0.98 for rounded orifice

0.82 for square edge orifice 


\begin{tabular}{lllll} 
& & \multicolumn{2}{c}{ HNF-SD-WM-CN-102 } & Rev 0 \\
c & Fluid & Dynamic & Respirable & RR Fitting \\
C & Specific & $\begin{array}{l}\text { Viscosity } \\
\text { C }\end{array}$ Gravity & Diameter & Constant \\
C & $\overline{1.41000 E+00}$ & $\overline{1.00000 E+00}$ & $\overline{1.45000 E+01}$ & $\overline{2.40000 E+00}$
\end{tabular}

\section{MESSAGES:}

Orifice Model

User specified orifice diameter or slit width.

\section{OUTPUT :}

Liquid Velocity $=4.53 \mathrm{E}+01 \mathrm{ft} / \mathrm{s} \quad 1.38 \mathrm{E}+01 \mathrm{~m} / \mathrm{s}$

Reynolds Number $=1.02 \mathrm{E}+06$ Turbulent Flow

Sauter Mean Diameter $=6.21 \mathrm{E}+04 \mu \mathrm{m}$

Respirable Fraction $=6.96 \mathrm{E}-10$

Total Leak Rate $=4.74 \mathrm{E}+02 \mathrm{gpm}$

Respirable Leak Rate $=3.30 \mathrm{E}-07 \mathrm{gpm}$

$2.99 \mathrm{E}-02 \mathrm{m3} / \mathrm{s}$

$2.08 \mathrm{E}-11 \mathrm{~m} 3 / \mathrm{s}$
$4.22 \mathrm{E}+04 \mathrm{~g} / \mathrm{s}$

$2.94 \mathrm{E}-05 \mathrm{~g} / \mathrm{s}$ 
HNF-SD-WM-CN-102 Rev 0

CHECKLIST FOR PEER REVIEW

Document Reviewed: RADIOLOGICAL AND TOXICOLOGICAL CONSEQUENCES OF A WORST-CASE SPRAY LEAK RELATED TO PROJECT $W-320$, D.A. Himes, 3/31/97

Scope of Review: entire document

$\frac{\operatorname{Yes} \text { No NA }}{[x][][] *}$

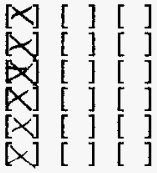

[ ] [ ] $[K]$

X] [ ] [ ]

[x] [ ] [ ]

[x] [ ] [ ]

[x] [ ] [ ]

[x] [ ] [ ]

$\left[\begin{array}{lll}{[} & {[} & {[x]} \\ E\end{array}\right]\left[\begin{array}{ll}] & {[}\end{array}\right]$

[×] [ ] [ ]

[ ] [ ] $\mathbb{x}]$

[ ] []*

[×].[ ] [ ] Document approved. applicable. of results. document reviewed. limits. statement. standards
Previous reviews complete and cover analysis, up to scope of this review, with no gaps.

Problem completely defined.

Accident scenarios developed in a clear and logical manner.

Necessary assumptions explicitly stated and supported.

Computer codes and data files documented.

Data used in calculations explicitly stated in document.

Data checked for consistency with original source information as

Mathematical derivations checked including dimensional consistency

Models appropriate and used within range of validity or use outside range of established validity justified.

Hand calculations checked for errors. Spreadsheet results should be treated exactly the same as hand calculations.

Software input correct and consistent with document reviewed.

Software output consistent with input and with results reported in

Limits/criteria/guidelines applied to analysis results are appropriate and referenced. Limits/criteria/guidelines checked against references.

Safety margins consistent with good engineering practices.

Conclusions consistent with analytical results and applicable

Results and conclusions address all points required in the problem

Format consistent with appropriate NRC Regulatory Guide or other

Review calculations, comments, and/or notes are attached.

* Any calculations, comments, or notes generated as part of this review should be signed, dated and attached to this checklist. Such material should be labeled and recorded in such a manner as to be intelligible to a technically qualified third party. 


\section{HEDOP REVIEW CHECKLIST \\ for}

Radiological and Nonradiological Release Calculations

Document reviewed (include title or description of calculation, document number, author, and date, as applicable):

Radiological and Toxicological Consequences of a Worst-Case Spray Leak Related to Project W-320, HNF-SD-WM-CN-102, Rev. 0, D. A. Himes
Submitted by:
D. A. Himes
Date Submitted: $04 / 30 / 97$

Scope of Review: Entire document

YES NO* N/A

[ $]$ [ ] [ ] 1. A detailed technical review and approval of the environmental transport and dose calculation portion of the analysis has been performed and documented.

[V] [ ] [ ] 2. Detailed technical review(s) and approval(s) of scenario and release determinations have been performed and documented.

[ ] [ ] [ $[/$ 3. HEDOP-approved code(s) were used.

[J] [ ] [ ] 4. Receptor locations were selected according to HEDOP recommendations.

[J] [ ] [ ] 5. Al1 applicable environmental pathways and code options were

[J] [ ] [ ] 6. Hanford site data were used.

[ ] [ ] [J] 7. Model adjustments external to the computer program were justified and performed correctly.

[V] [ ] [ ] 8. The analys is is consistent with HEDOP recommendations.

[] [J] 9. Supporting notes, calculations, comments, comment resolutions, or other information is attached. (Use the "Page 1 of $X "$ page numbering format and sign and date each added page.)

[J] [ ] 10. Approval is granted on behalf of the Hanford Environmental Dose Overview Panel.

* A1l "NO" responses must be explained and use of nonstandard methods justified.

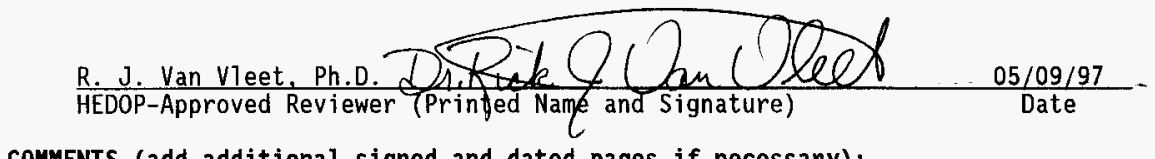

COMMENTS (add additional signed and dated pages if necessary): 


\section{DISTRIBUTION SHEET}

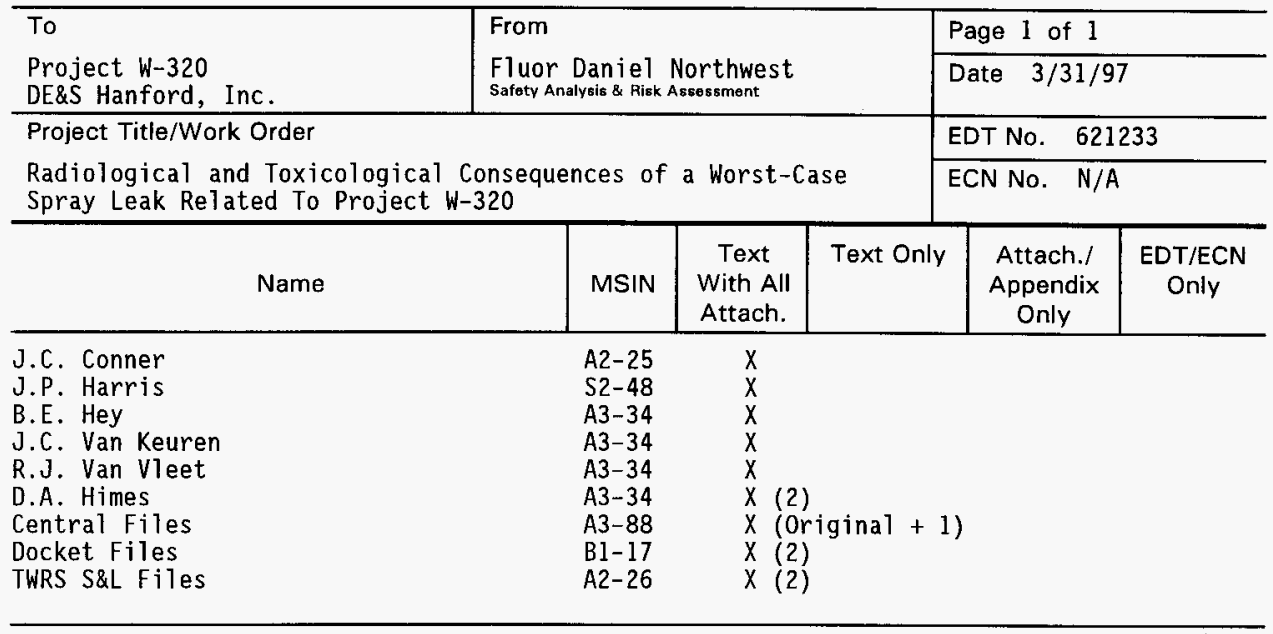

